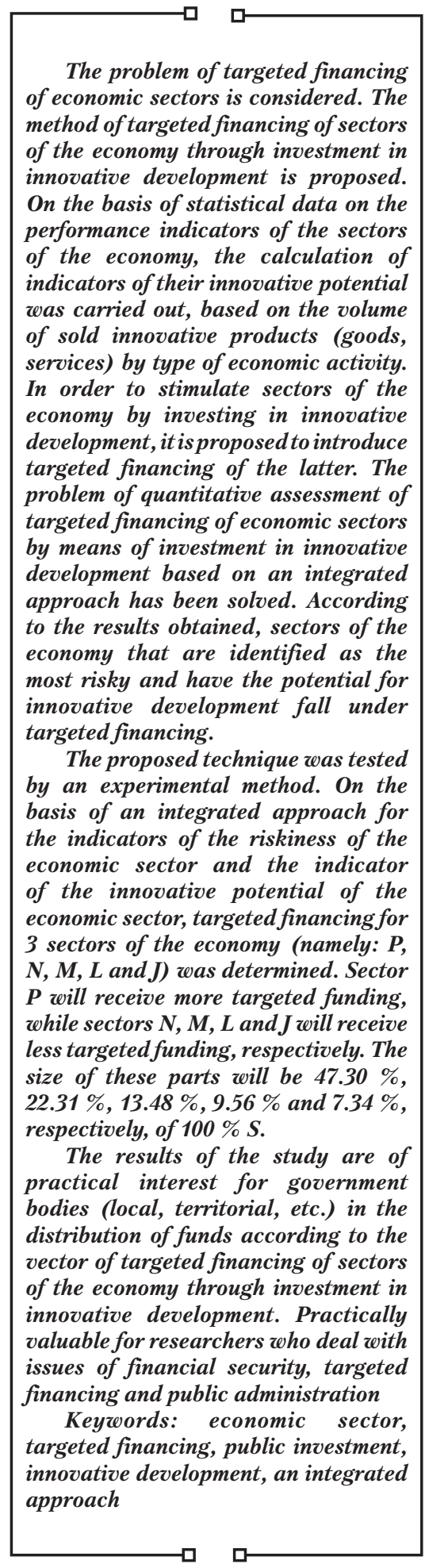

UDC 658.589

DOI: $10.15587 / 1729-4061.2021 .243235$

\section{DEVELOPMENT OF A METHOD FOR TARGETED FINANCING OF ECONOMY SECTORS THROUGH CAPITAL INVESTMENT IN THE INNOVATIVE DEVELOPMENT}

\author{
Iaroslava Levchenko \\ Corresponding author \\ Doctor of Economic Sciences, Associate Professor \\ Department of Economics and Business \\ Kharkiv National Automobile and Highway University \\ Yaroslava Mudroho str., 25, Kharkiv, Ukraine, 61002 \\ E-mail: slavalevcenko1984@gmail.com \\ Peter Losonczi \\ $\mathrm{PhD}$, Associate Professor \\ Department of Civil Security \\ University of Security Management in Kosice \\ Kostova str., 2373/1, Kosice, Slovakia, 04001 \\ Igor Britchenko \\ Doctor of Economics, Professor \\ Department of Technical and Economic Sciences
} State Higher Vocational School Memorial of Prof. Stanislaw Tarnowski in Tarnobrzeg Henryka Sienkiewicza str., 50, Tarnobrzeg, Poland, 39-400

Radostin Vazov

PhD, Associate Professor, Vice-Rector for European Projects and Further Education

Department of Insurance

VUZF University (Higher School of Insurance and Finance)

Gusla srt., 1, Ovcha kupel, Sofia, Bulgaria, 1618

O Iga Zaiats

$\mathrm{PhD}$, Associate Professor

Department of Management

National Transport University

M. Omelianovycha-Pavlenka str., 1, Kyiv, Ukraine, 01010

Viktoria Volodavchyk

PhD, Associate Professor

Department of Commodity Research, Commercial Business and Goods Examination Luhansk Taras Shevchenko National University Hoholia sq., 1, Starobilsk, Ukraine, 92703

I ryna Humeniuk $\mathrm{PhD}$

Educational and Rehabilitation Institution of Higher Education Kamianets-Podilskyi State Institute Godovantsa str., 13, Kamianets-Podilskyi, Ukraine, 32300

Oleksi i Shumilo

$\mathrm{PhD}$, Associate Professor

Department of Legal Support of Economic Activity Kharkiv National University of Internal Affairs Lva Landau ave., 27, Kharkiv, Ukraine, 61080
Received date 18.09.2021 Accepted date 23.10.2021 Published date 29.10.2021
How to Cite: Levchenko, I., Losonczi, P., Britchenko, I., Vazov, R., Zaiats, O., Volodavchyk, V., Humeniuk, I., Shumilo, O. (2021). Development of a method for targeted financing of economy sectors through capital investment in the innovative development. Eastern-European Journal of Enterprise Technologies, 5 (13 (113)), 6-13. doi: https://doi.org/10.15587/1729-4061.2021.243235

\section{Introduction}

The development of each separate sector of the economy is the development of the state as a whole. For the development of all sectors of the economy of each country, without exception, new ideas and the implementation of the latest technologies are needed. It is about innovative development [1,2]. Over the period 2010-2020, the world 
has witnessed an explosion of innovation in all areas. Innovation has forever changed everyday life and the way we work. Researchers all over the world are unanimous that the speed of this development will not decrease, but, on the contrary, will be faster. This decade (2021-2030) will also see breakthroughs that are impossible to imagine today. In the era of transience, it is startups, start-up projects, new ideas or innovative technological solutions that solve a number of problematic issues in all sectors of the economy along the vector of innovative development. However, to implement such ideas, financial resources are needed.

Some researchers propose to solve the problem of financing exclusively through government intervention, since it is about the need for significant capital investments [3]. However, the COVID crisis has revealed a huge number of ways to ensure innovative development. All countries, UN, donors, FOUNDER seek to finance such ways of providing. Each party, interested in innovative development, must carry out investment injections (finance, support, subsidize) in order to ensure the latter [4-6]. This provokes solutions to some scientific problems, namely: how, to whom and how much to allocate financial resources to ensure the implementation of innovative development. State administration of financing the sectors of the economy by investing in innovative development aims at obtaining, as a result, new solutions and start-up projects for the country's enterprises operating in this sector of the economy. Those sectors that have the potential for implementation and aim to increase competitiveness through the implementation of innovative high-quality products are a need for the $21^{\text {st }}$ century. In turn, the latest techniques should provide additional motivation for economic sectors by investing in their innovative development. Summarizing, on the one hand, it is necessary to ensure innovative development, on the other - the sectors of the economy, which, while ensuring the vector of innovation, require new forms of financing [7]. This gives rise to the need for new copyright methods to provide additional motivation for funding, which is a necessity for scientific research.

\section{Literature review and problem statement}

Providing an innovative vector of development is the foundation for industry productivity and its competitiveness [8]. In an era of turbulence, only the development of innovations is the key to the growth of the state's economy [9]. Innovation is not only a transformation tool of the past decade. Innovative capital investments in a broad sense are long-term and, very often, one-time infusions with the aim of stimulating generation, supporting the development and ensuring the implementation of innovations, their practical application for the purpose of innovative development in general. Effective generation, management and financing of the innovation vector are those issues that do not lose their relevance, since they are a powerful engine for the development of all mankind [10].

Innovative development has a positive effect on all sectors of the economy [11]. For example, the University of Oxford conducts research and creates innovative products every 2 months [12]. The creation of such new products directly provides the university with finance, contributes to local economic development and the creation of many new jobs in the region. The benefits are clear to everyone involved. And such a system of financing innovative development is viable only if well-coordinated work between the state and stakeholders, in the role of which is the economic sector in the context of this study. Talking about financing the innovation vector of all sectors of the country's economy is hardly acceptable in the face of turbulent challenges. In the context of an integrated economy in innovative development [13], targeted financing of sectors of the economy through investment in innovative development forces each state. Therefore, there is a need to develop a methodology for targeted financing of sectors of the economy through investment in innovative development.

Modern methods of financing do not give an answer to the question of how to conduct targeted financing from the standpoint of the innovation component and how to determine the sectors of the economy when implementing the same targeted financing.

The research team [14] analyzed and discussed some of the modern funding methods. Among these are the following: intergovernmental financing, loan guarantees, etc. The focus of the study is aimed at the fact that financing of large infrastructure and other events should be provided not only from the state, but also from the regions. However, this study does not say anything about what underlies targeted financing and how to select for targeted financing.

In part, the answer to this question can be found in the study [15], which proposes a financing method based on the indicator of investment attractiveness. The technique has practical value due to its complexity in assessing investment attractiveness, on the basis of which it is proposed to finance. This technique is valuable - it is theoretical in nature and can be adapted to assess the investment attractiveness of a sector of the economy. However, there is no answer to the question of how to combine the attractiveness of the region from the standpoint of the innovative vector of development, and nothing is said about solving the problem of quantitative assessment of targeted financing.

It should be noted that among researchers dealing with the problems of financial security, a fairly popular direction is the inclusion of an indicator of investment attractiveness in the methods [16].

So, another representative is the study [17], where the authors proposed a model of financing cities, which is based on the investment attractiveness of the latter. The complexity of this methodology, provided by the complexity of assessing investment attractiveness, is of unconditional practical interest. However, the study does not highlight the following problematic issues, such as: to whom should the finances be addressed, why exactly in that place the financing is being carried out and how much should be spent on financing. The theoretical component of the study [17] does not provide answers to these questions, so they remain open.

A comprehensive methodology was proposed in the study [16], where the authors proposed a financing methodology based on selective territorial financing. The idea of providing selective financing is also supported in the study [17], where state support and selective financing is interpreted as the basis for the development of the latter's economies. The authors of [17] proposed an interesting method of financial support based on a combination of private and public funds. And here it is about public-private partnership, and attention is paid to the methodology for determining the share of private funds. The issue of equitable distribution of public funds based on mathematical calculations was ignored. 
The studies and methodologies proposed by [14-17] are unanimous in their complexity and preliminary assessment. Researchers $[18,19]$ also spoke in support of selective financing, where they proved the need for an integrated approach to such an assessment and a comprehensive approach to financing the innovative orientation of the state of Poland. It was also emphasized about the need to support a branched vector of support for innovation, instead of a narrowly focused one [19]. This approach of complexity is inherent and is of practical interest from the countries of both Europe and the whole world.

Another complex method for determining the integral indicator of the investment attractiveness of specific innovative projects is proposed in [20]. This technique allows to make a well-grounded management decision on the formation of the investment strategy of the enterprise. The special value of the study is to highlight the most essential components that affect the dynamics of change in the innovation and investment characteristics of the entire industry. However, it focuses on energy enterprises and, accordingly, on one industry - energy.

After analyzing the studies [13-20], it can be stated that the problem of targeted financing of sectors of the economy through investment in innovative development has not been considered by other researchers. This indicates the need for additional research and development of a methodology for targeted financing of sectors of the economy through investment in innovative development has not been considered by other researchers.

\section{The aim and objectives of research}

The aim of research is to develop a methodology for targeted financing of sectors of the economy through investment in innovative development. This will make it possible to financially support innovation-oriented sectors of the economy on the part of the state on the path of innovative development of the latter.

To achieve this aim, the following research objectives were set:

- to introduce the concept of targeted financing in order to support sectors of the economy by investing in innovative development;

- to solve the problem of quantitative assessment of targeted financing of sectors of the economy through investment in innovative development.

\section{Materials and methods of research}

The object of research is the sectors of the economy, and the subject of the research is the available methods of financing them. In order to solve the problem of financing sectors of the economy by investing in innovative development with the aim of rehabilitating the state economy, it is proposed to use mathematical models [21].

As proved in the study [22], in order to obtain reliable information, the entire data set must contain a small amount of statistical data, which, in turn, must be as informative as possible.

To model targeted financing of sectors of the economy through investment in innovative development, two important indicators will be needed, namely:
- an indicator of the riskiness of a sector of the economy, is considered the most important indicator for financing $[23,24]$;

- an indicator of the innovative potential of the sector of the economy from the production of innovations.

To calculate the riskiness indicator of the economic sector, it is defined as the most important indicator for financing, based on the results of the research by Euler Hermes. The Euler Hermes database contains more than 80 million companies in various sectors of the economy [25]. Euler Hermes is constantly engaged in research and monitoring of various companies in various sectors of the economy, accounting for $92 \%$ of world GDP. According to the results of 2020 monitoring among 126 sectors of the economy, Euler Hermes experts recorded a significant amount of deterioration in the risk indicator by sector. The deterioration of the situation and the change in the impact on the riskiness of sectors of the economy, Euler Hermes experts associate with the direct and indirect impact of the Covid-19 coronavirus pandemic, including [25]. So, the indicator of the riskiness of the sector of the economy is taken the value of the indicator, which is obtained on the basis of a comprehensive study [26].

The methodology for calculating the indicator of the riskiness of the sector of the economy is presented in the study [27]. A value of 0 means that the sector of the economy is considered risk-free and not significantly sensitive to the impact of Covid-19. Values from 0 to 1 indicate that the sector is considered risky and sensitive to the impact of Covid-19 [28]. Euler Hermes experts deliberately focused attention on the sensitivity to the effects of Covid-19, since in 2020-2021 the latter was recognized as the greatest risk, the impact of which is extremely difficult to assess or overestimate.

Table 1 shows the riskiness of sectors of the economy [26].

Table 1

The riskiness of sectors of the economy (built by the author on the basis of $[26,27])$

\begin{tabular}{|c|c|}
\hline Economic sector & Risk of the sector \\
\hline $\begin{array}{c}\text { Manufacture of computers and telecommuni- } \\
\text { cations equipment }\end{array}$ & 0.03 \\
\hline Textile industry & 0.07 \\
\hline Manufacture of household appliances & 0.07 \\
\hline Construction & 0.22 \\
\hline $\begin{array}{c}\text { Delivery of automotive components and } \\
\text { parts }\end{array}$ & 0.5 \\
\hline Electronics industry & 0.5 \\
\hline Trade & 0.5 \\
\hline Software development, IT services & 0.5 \\
\hline Chemical industry & 0.58 \\
\hline Mechanical engineering & 0.58 \\
\hline Paper production & 0.6 \\
\hline Automotive industry & 0.7 \\
\hline Vehicle production & 0.7 \\
\hline Energy & 0.97 \\
\hline Agricultural industry & 0.63 \\
\hline Transport & 1 \\
\hline & \\
\hline & \\
\hline
\end{tabular}

A number of sectors of the economy are affected by the sectors of the countries of the world. Quarantine measures hit airlines, the automotive sector, where the market is 
threatened with a drop in all performance indicators. The trade and supply sector is at risk in cross-border supply chains. The electronics industry is facing weakening demand in Europe, where electronics sales have declined significantly. In general, large-scale losses were inflicted on the sectors of the economies of Western Europe and Asia.

At the second stage, the calculation of the indicator of the innovative potential of the economic sector from the production of innovations is presented on the basis of open statistical information on the indicator of the volume of sold innovative products (goods, services) by type of economic activity in 2020 [29].

For approbation of the methodology, 16 sectors of the Ukrainian economy were selected, for the further presentation of the hierarchy, the symbols assigned to them and the parameters are presented in Table 2.

Table 2

The volume of sold innovative products (goods, services) by type of economic activity in 2020 [29]

\begin{tabular}{|c|c|c|c|}
\hline \multirow[t]{2}{*}{ Economic sector } & \multirow{2}{*}{$\begin{array}{l}\text { The convention- } \\
\text { al name of the } \\
\text { economic sector }\end{array}$} & \multicolumn{2}{|c|}{$\begin{array}{c}\text { The volume of } \\
\text { sold innovative } \\
\text { products }\end{array}$} \\
\hline & & million c.u. & $\%$ \\
\hline $\begin{array}{c}\text { Manufacture of computers } \\
\text { and telecommunications } \\
\text { equipment }\end{array}$ & A & 1452.6 & 9.3 \\
\hline Textile industry & $\mathrm{B}$ & 102.9 & 1.4 \\
\hline $\begin{array}{l}\text { Manufacture of household } \\
\text { appliances }\end{array}$ & $\mathrm{C}$ & 1459.9 & 6.8 \\
\hline Construction & $\mathrm{D}$ & 0 & 0 \\
\hline $\begin{array}{c}\text { Delivery of automotive } \\
\text { components and parts }\end{array}$ & $\mathrm{E}$ & 0 & 0 \\
\hline Electronics industry & $\mathrm{F}$ & 2470.3 & 6.8 \\
\hline Trade & G & 1841.2 & 0.1 \\
\hline $\begin{array}{c}\text { Software development, IT } \\
\text { services }\end{array}$ & $\mathrm{H}$ & 411.4 & 0.8 \\
\hline Chemical industry & I & 1030.0 & 1.3 \\
\hline Mechanical engineering & $\mathrm{J}$ & 3803.1 & 5.4 \\
\hline Paper production & $\mathrm{K}$ & 252.8 & 0.7 \\
\hline Automotive industry & $\mathrm{L}$ & 1516.2 & 5.1 \\
\hline Vehicle production & M & 2060.4 & 4.5 \\
\hline Energy & $\mathrm{N}$ & 169.9 & 0.0 \\
\hline Agricultural industry & $\mathrm{O}$ & 0 & 0 \\
\hline Transport & $\mathrm{P}$ & 1602.3 & 0.4 \\
\hline$\ldots$ & $\ldots$ & $\ldots$ & $\ldots$ \\
\hline Total & & 59508,98 & 100 \\
\hline
\end{tabular}

It is worth noting that for the sake of simplicity, it is customary to designate the names of the sectors of the Ukrainian economy with the letters A-P.

Next, let's calculate the indicator of the innovative potential of the economic sector for the state based on their classification according to the results presented in Table 2.

Table 3 shows the calculated information.

A method of targeted financing of sectors of the economy through investment in innovative development, based on the indicators of the riskiness of the sector of the economy and the indicator of the innovative potential of the sector of the economy from the production of innovations, is proposed.
Table 3

Indicator of the innovative potential of the sector of the economy for the state

\begin{tabular}{|c|c|c|}
\hline Economic sector & $\begin{array}{c}\text { The con- } \\
\text { ventional } \\
\text { name of the } \\
\text { economic } \\
\text { sector }\end{array}$ & $\begin{array}{c}\text { Indicator of } \\
\text { the innovative } \\
\text { potential of } \\
\text { the economic } \\
\text { sector for the } \\
\text { state }\end{array}$ \\
\hline $\begin{array}{c}\text { Manufacture of computers and } \\
\text { telecommunications equipment }\end{array}$ & $\mathrm{A}$ & 0.0799 \\
\hline Textile industry & $\mathrm{B}$ & 0.0057 \\
\hline $\begin{array}{c}\text { Manufacture of household } \\
\text { appliances }\end{array}$ & $\mathrm{C}$ & 0.0803 \\
\hline Construction & $\mathrm{D}$ & 0.0000 \\
\hline $\begin{array}{c}\text { Delivery of automotive compo- } \\
\text { nents and parts }\end{array}$ & $\mathrm{E}$ & 0.0000 \\
\hline Electronics industry & $\mathrm{F}$ & 0.1359 \\
\hline Trade & $\mathrm{G}$ & 0.1013 \\
\hline Software development, IT & $\mathrm{H}$ & 0.0226 \\
\hline services & $\mathrm{I}$ & 0.0567 \\
\hline Chemical industry & $\mathrm{J}$ & 0.2093 \\
\hline Mechanical engineering & $\mathrm{K}$ & 0.0139 \\
\hline Paper production & $\mathrm{L}$ & 0.0834 \\
\hline Automotive industry & $\mathrm{M}$ & 0.1134 \\
\hline Vehicle production & $\mathrm{N}$ & 0.0093 \\
\hline Energy & $\mathrm{O}$ & 0.0000 \\
\hline Agricultural industry & $\mathrm{P}$ & 0.0882 \\
\hline Transport & & \\
\hline
\end{tabular}

\section{The results of the development of a methodology for targeted financing of sectors of the economy through investment in innovative development}

5. 1. Proposals on the introduction of the concept of targeted financing of sectors of the economy

Targeted financing of sectors of the economy, according to the author's idea, is a part of the financial resources that are sent to the sector of the economy (recipient) in order to stimulate the latter to innovative development. Targeted financing is made on the basis of an integrated approach in terms of indicators of the riskiness of the sector of the economy and the indicator of the innovative potential of the sector of the economy from the production of innovations.

A hypothesis has been put forward about the following: the program for the development (stimulation) of economic sectors consists of $n$ number of sectors that are candidates for targeted financing. The index of the sector of the economy, takes part in the financing processes, will be designated as $i=\overline{1, n}$. Let the return on investment of the sector of the economy per unit of financial resources spent be $a_{i}\left(a_{i}\right.$ cannot be $\left.<1\right)$.

A formalized description of the model of effective cooperation between the economic sector and the financial donor (state or others) is proposed, which can be presented in the following form:

$$
Z_{\mathrm{i}}\left(S_{\mathrm{i}}, x_{\mathrm{i}}\right)=\varphi_{\mathrm{i}}\left(S_{\mathrm{i}}\right)-y_{\mathrm{i}}=\varphi_{\mathrm{i}}\left(S_{\mathrm{i}}\right)-\left(S_{\mathrm{i}}-x_{\mathrm{i}}\right), i=\overline{1, n} ;
$$

where $S_{i}$ - total amount of funding that is directed to innovative development;

$\varphi_{i}\left(S_{i}\right)$ - income of the $i$-th sector of the economy from the implementation of innovative development; 
$x_{i}-$ amount of financial resources of the economy sector for innovative development - borrowed funds;

$y_{i}$ - own financial resources of the economy sector to ensure innovative development;

$z_{i}$ - invested investments of a financial donor (government or others), which takes into account the volume of investments in innovative development;

$Z_{i}$ - net profit of the economic sector as part of its own financial resources (as part of $y_{i}$ ).

Under the conditions $\varphi_{i}\left(S_{i}\right)>x_{i}+y_{i}+z_{i}$ or $\varphi_{i}\left(S_{i}\right) /\left(x_{i}+y_{i}+z_{i}\right)>1$, the model of cooperation between the economic sector and the financial donor (state or others) is considered effective. The use of targeted investment optimizes the financing process and improves efficiency.

A prerequisite for calculations according to the proposed author's methodology is the presence of a synthetic (artificial) indicator $q_{i}$. The formula for calculating it (2) is pref sented below:

$$
\left(1-a_{i}\right) / l_{i}=q_{i}
$$

where $a_{i}$ - efficiency, which is estimated by the return on the economic sector per unit of invested financial resources; $l_{i}-$ priority.

Instead of the efficiency indicator, the indicator of the innovative potential of the economic sector from the production of innovations $(r)$ is substituted, and instead of the priority indicator, the indicator of the riskiness of the economic sector $(R)$. The artificial index $q_{i}$ is calculated according to the formula (3):

$$
\left(1-r_{i}\right) / R_{\mathrm{i}}=q_{i},
$$

where $r_{i}$ - indicator of the innovative potential of the $i$-th sector of the economy from the implementation of innovations, c. u.; $R_{i}$ - indicator of the riskiness of the sector of the economy, conv. Unit

The next stage is filtering from the smallest $q_{i}$ value of the corresponding sectors of the economy to the largest $q_{i}$ value.

To determine the list of sectors of the economy that can qualify for financing, their maximum value $\mathrm{n}$ is determined that would satisfy the following inequality:

$$
q_{i}<Q_{n} /(n-1),
$$

where $Q_{n}$ - sum of artificial indicators $q_{i}$ corresponding to sectors of the economy $n$.

Enumeration and calculations by formula (4) are carried out as long as condition (4) is satisfied. When condition (4) is not met, the calculation ends and the following sectors of the economy are excluded from the list of applicants for capital investments in innovative development in order to rehabilitate the state economy.

\section{2. Formulation and solution of the problem of quan-} titative assessment of targeted financing of sectors of the economy

To determine the rate of targeted financing of sectors of the economy, the entire procedure of which is presented by formulas (1)-(4) of this study, at the initial stage it is neces- sary to calculate the synthetic indicator $q_{i}$. The initial data for the calculation are presented in Tables 1, 2 .

The calculation of $q_{i}$ is made according to the formula (3) and is presented in Table 4.

Table 4

The results of calculating the value of $q_{i}$

\begin{tabular}{|c|c|c|c|}
\hline $\begin{array}{c}\text { The conven- } \\
\text { tional name of } \\
\text { the economic } \\
\text { sector }\end{array}$ & $\begin{array}{c}\text { Risk } \\
\text { of the } \\
\text { sector }\end{array}$ & $\begin{array}{c}\text { Indicator of the innovative } \\
\text { potential of the economic sec- } \\
\text { tor from the implementation } \\
\text { of innovations, } r\end{array}$ & $q_{i}$ value \\
\hline A & 0.03 & 0.0799 & 0.9118 \\
\hline B & 0.07 & 0.0057 & 1.0213 \\
\hline C & 0.07 & 0.0803 & 1.2666 \\
\hline D & 0.22 & 0.0000 & 1.3094 \\
\hline E & 0.5 & 0.0000 & 1.3633 \\
\hline F & 0.5 & 0.1359 & 1.5873 \\
\hline G & 0.5 & 0.1013 & 1.6264 \\
\hline H & 0.5 & 0.0226 & 1.6435 \\
\hline I & 0.58 & 0.0567 & 1.7282 \\
\hline J & 0.58 & 0.2093 & 1.7974 \\
\hline K & 0.6 & 0.0139 & 1.9548 \\
\hline L & 0.7 & 0.0834 & 2.0000 \\
\hline $\mathrm{M}$ & 0.7 & 0.1134 & 4.5455 \\
\hline $\mathrm{N}$ & 0.97 & 0.0093 & 13.1386 \\
\hline $\mathrm{O}$ & 0.63 & 0.0000 & 14.2043 \\
\hline $\mathrm{P}$ & 1 & 0.0882 & 30.6700 \\
\hline
\end{tabular}

When determining the share of targeted financing of the sector of the economy, according to the proposed author's methodology, it is necessary to sort the latter from small to large by the value of $q_{i}$. The calculation results in the order of increasing $q_{i}$ are shown in Fig. 1.

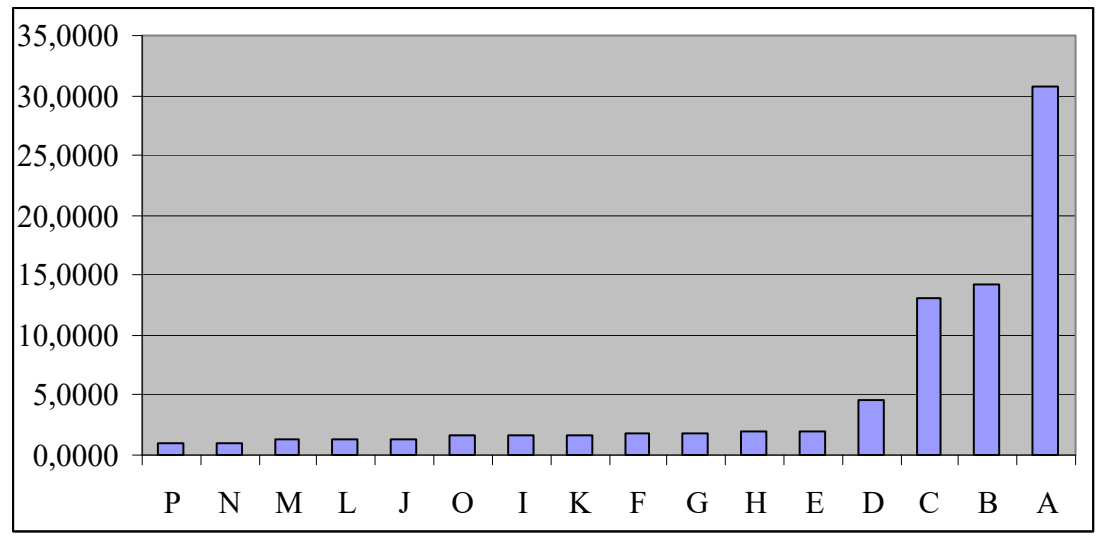

Fig. 1. The value of $q_{i}$, presented in ascending order

The whole algorithm of the procedure for determining the number of sectors of the economy to receive financing can be represented by inequality (4).

Next, the fulfillment of the specified condition (4) is checked for 16 obtained values of $q_{i}$. Checking the fulfillment of condition (4) will be carried out as long as the latter is fulfilled. When condition (4) is not met, the calculations are stopped, and the following sectors of the economy are excluded from the list of applicants for funding for innovative development. 
The calculation results are presented in Table 5.

Table 5

Checking the fulfillment of condition (4)

\begin{tabular}{|c|c|c|c|c|}
\hline $\begin{array}{c}\text { Number of } \\
\text { sectors of } \\
\text { the econo- } \\
\text { my, } n\end{array}$ & $q_{i}$ & $\begin{array}{c}\sum q_{i} \text { which } \\
\text { corresponds } \\
n, Q_{n}\end{array}$ & $Q_{n} /(n-1)$ & $\begin{array}{c}\text { Checking the } \\
\text { fulfillment of the } \\
\text { condition (4) }\end{array}$ \\
\hline 2 & 1.0213 & 1.9331 & 1.9331 & $1.9331>1.0213$ \\
\hline 3 & 1.2666 & 3.1997 & 1.5998 & $1.5998>1.2666$ \\
\hline 4 & 1.3094 & 4.5091 & 1.5030 & $1.5030>1.3094$ \\
\hline 5 & 1.3633 & 5.8724 & 1.4681 & $1.4681>1.3633$ \\
\hline 6 & 1.5873 & 7.4597 & 1.4919 & $1.4919<1.5873$ \\
\hline
\end{tabular}

Since condition (4) is not satisfied for $n=6$, the calculations must be completed. This means that the sectors of the economy have been identified to receive targeted financing. These are the sectors $\mathrm{P}, \mathrm{N}, \mathrm{M}, \mathrm{L}$ and $\mathrm{J}$ with the values of the indicator of the innovative potential of the sector of the economy from the implementation of innovations of 0.0882 ; $0.0093 ; 0.1134 ; 0.0834$ and 0.2093 , respectively. At the same time, the indicators of the sector's riskiness are 1, 0.97, 0.7, 0.7 and 0.58 , respectively. This proves the significant influence of these two components on the definition of targeted financing.

Next, a quantitative assessment of targeted financing of sectors of the economy by investment in innovative development is carried out, with the allocated funds equal to 1 , in proportion to the received $\mathrm{Q}_{n} /(n-1)$. The results are presented in Table 6 .

Table 6

Quantitative assessment of targeted financing of sectors of the economy through investment in innovative development ( $S=1)$

\begin{tabular}{|c|c|c|}
\hline Economic sector & $\begin{array}{c}\text { The conventional } \\
\text { name of the eco- } \\
\text { nomic sector }\end{array}$ & $\begin{array}{c}\text { Targeted financing } \\
\text { for } S=1\end{array}$ \\
\hline Transport & $\mathrm{P}$ & 0.4730 \\
\hline Energy & $\mathrm{N}$ & 0.2231 \\
\hline Vehicle production & $\mathrm{M}$ & 0.1348 \\
\hline Automotive industry & $\mathrm{L}$ & 0.0956 \\
\hline Mechanical engineering & $\mathrm{J}$ & 0.0734 \\
\hline
\end{tabular}

As shown by the calculations presented in Tables $6,5 \mathrm{sec}-$ tors of the economy (namely: $\mathrm{P}, \mathrm{N}, \mathrm{M}, \mathrm{L}$ and $\mathrm{J}$ ) will receive targeted financing for innovative development. Sector $\mathrm{P}$ will receive more targeted funding, while sectors $\mathrm{N}, \mathrm{M}, \mathrm{L}$ and $\mathrm{J}$ will receive less funding, respectively. The size of these parts will be $47.30 \%, 22.31 \%, 13.48 \%, 9.56 \%$ and $7.34 \%$, respectively, of $100 \% \mathrm{~S}$.

\section{Discussion of the results of developing a methodology for targeted financing of sectors of the economy through investment in innovative development}

A large number of methods of financing sectors of the economy have been proposed by modern researchers [13-20]. They are all integral and complex. Some methods contain more indicators for calculations, others - fewer. The methodology of targeted financing of economic sectors proposed by the authors in this study by means of investment in inno- vative development. It is built on the basis of the obtained indicators of the riskiness of the economic sector and the indicator of the innovative potential of the economic sector from the production of innovations; it is also complex. It contains the most important component - targeted financing. According to the author's definition, targeted financing of sectors of the economy is a part of the financial resources that are sent to the sector of the economy (recipient) in order to stimulate the latter to innovative development. Targeted financing is made on the basis of an integrated approach in terms of indicators of the riskiness of the sector of the economy and the indicator of the innovative potential of the sector of the economy from the production of innovations. The proposed methodology makes it possible to determine the potentially best sectors of the economy by the vector of innovative development based on an integrated approach.

Unlike existing methods, the author's one is aimed at supporting the innovative development of not only a separate sector of the economy, but also the state as a whole. It was determined that the sectors of the economy that effectively use the innovative and scientific potential receive targeted funding. The volume of sold innovative products (goods, services) by types of economic activity in 2020 was taken as a basis (Table 2) and the indicator of the innovative potential of the economy sector for the state was calculated (Table 3 ). The presence of a mathematical justification for targeted financing is also a distinctive characteristic of the author's methodology.

In order to stimulate the sectors of the economy to innovative development, it was proposed to introduce targeted investment, the calculation procedure of which is presented by formulas (1)-(4) of this study and its approbation was carried out.

When determining the share of targeted financing of the economic sector, $q_{i}$ was calculated and the results of the latter were sorted from small to large, and the calculation results are presented in Fig. 1. Next, the problem of quantitative assessment of targeted financing of sectors of the economy by investment in innovative development based on an integrated approach was solved. The complexity is provided by indicators of the riskiness of the economic sector and the indicator of the innovative potential of the economic sector from the production of innovations for 5 sectors of the economy, the results of which are presented in Table 6. More targeted funding will receive $\mathrm{P}$, and less - sectors $\mathrm{N}, \mathrm{M}, \mathrm{L}$ and $\mathrm{J}$, respectively.

The results obtained make it possible to solve the problem of targeted financing of sectors of the economy by investing in innovative development, which has not been considered by other researchers. The practical scope of application is for government bodies (local, territorial, etc.) When distributing funds according to the vector of targeted financing of sectors of the economy by investing in innovative development. From a theoretical point of view, the results can be useful to researchers who deal with issues of financial security, targeted financing and public administration.

The main limitation of the study is that the methodology does not take into account the scale of the economic sector, the elimination of which is possible with the implementation of the methodology of appropriate correction factors.

Research is practically interesting for government bodies (local, territorial, etc.) when distributing funds according to the vector of targeted financing of sectors of the economy by investing in innovative development. The theoretical value of the 
research is presented to researchers who deal with issues of financial security, targeted financing and public administration.

\section{Conclusions}

1. The implementation of targeted financing is proposed to stimulate sectors of the economy to innovative development. When calculating according to the author's methodology, the income and expenses of 16 sectors of the economy that were selected were taken into account. A formalized description of the model of effective cooperation between the economic sector and the financial donor (state or others) is proposed.
2. The problem of quantitative assessment of targeted financing of sectors of the economy through investment in innovative development is solved based on an integrated approach. Complexity is provided by indicators of the riskiness of the economic sector and the indicator of the innovative potential of the economic sector from the production of innovations for 5 sectors of the economy (namely: P, N, M, L and J). Sector P will receive more targeted funding, while sectors $\mathrm{N}, \mathrm{M}, \mathrm{L}$ and $\mathrm{J}$ will receive less funding, respectively. The size of these parts will be $47.30 \%, 22.31 \%, 13.48 \%, 9.56 \%$ and $7.34 \%$, respectively, of $100 \% \mathrm{~S}$ (the total amount of funding that is directed to innovative development).

\section{References}

1. Keskin, G., Basal, T. (2014). Kazakhstan invests in science for economic growth. Available at: https://www.elsevier.com/connect/ kazakhstan-invests-in-science-for-economic-growth

2. Kisjes, I. (2013). The Impact of Science: how research can be measured and spending maximized. Available at: https://www.elsevier. com/connect/the-impact-of-science-how-research-can-be-measured-and-spending-maximized

3. Mihaylova, M. (2021). Innovation through the prism of companies using direct marketing. An empirical example from Bulgaria. VUZF Review, 6 (2), 11-15. doi: https://doi.org/10.38188/2534-9228.21.2.02

4. Maximizing Investments \& Accelerating The Journey To Research Innovation. Available at: https://www.elsevier.com/_data/ assets/pdf_file/0010/259435/Maximizing-Investments-and-Accelerating-The-Journey-To-Research-Innovation.pdf

5. Investing in innovation. Technology promises a brighter, more productive future. Available at: https://www.washingtonpost.com/ sf/brand-connect/oppenheimerfunds/investing-in-innovation/

6. Investing in innovation. Available at: https://www.minneapolisfed.org/article/2019/investing-in-innovation

7. Kukacka, J., Kristoufek, L. (2020). Do "complex" financial models really lead to complex dynamics? Agent-based models and multifractality. Journal of Economic Dynamics and Control, 113, 103855. doi: https://doi.org/10.1016/j.jedc.2020.103855

8. Grosse Kathoefer, D., Leker, J. (2012). Knowledge transfer in academia: an exploratory study on the Not-Invented-Here Syndrome. The Journal of Technology Transfer, 37 (5), 658-675. doi: https://doi.org/10.1007/s10961-010-9204-5

9. Lopes, A. P. V. B. V., Kissimoto, K. O., Salerno, M. S., Carvalho, M. M. de, Laurindo, F. J. B. (2016). Innovation management: a systematic literature analysis of the innovation management evolution. Brazilian Journal of Operations \& Production Management, 13 (1), 16. doi: https://doi.org/10.14488/bjopm.2016.v13.n1.a2

10. Yordanova, Z. (2019). A model for evaluation of innovative universities. Educational Innovations and Applications. doi: https:// doi.org/10.35745/ecei2019v2.117

11. Cherniavskyi, B., Vazov, R. (2020). Innovative logistics as a tool to increase the competitiveness of the polish construction industry. VUZF Review, 5 (2), 3-10. doi: https://doi.org/10.38188/2534-9228.20.2.01

12. Investments. Available at: https://innovation.ox.ac.uk/portfolio/

13. Trusova, N., Hryvkivska, O. (2021). The development of integrated business structures of Ukraine on innovative and investment basis. VUZF Review, 6 (1), 87-97. doi: https://doi.org/10.38188/2534-9228.21.6.09

14. Terlikowski, P., Paska, J., Pawlak, K., Kaliński, J., Urbanek, D. (2019). Modern financial models of nuclear power plants. Progress in Nuclear Energy, 110, 30-33. doi: https://doi.org/10.1016/j.pnucene.2018.09.010

15. Snieska, V., Zykiene, I. (2015). City Attractiveness for Investment: Characteristics and Underlying Factors. Procedia - Social and Behavioral Sciences, 213, 48-54. doi: https://doi.org/10.1016/j.sbspro.2015.11.402

16. Levchenko, I., Britchenko, I. (2021). Estimation of state financial support for non-priority territorial units using the example of bridge construction. Eastern-European Journal of Enterprise Technologies, 1 (13 (109)), 26-34. doi: https://doi.org/10.15587/ 1729-4061.2021.225524

17. Urbancikova, N., Burger, P. (2014). Financing Clusters from Public Funds in the European Countries. Journal of Applied Economic Sciences, 9 (1 (27)), 148-157. Available at: https://www.researchgate.net/publication/262791406_Financing_Clusters_from_ Public_Funds_in_the_European_Countries

18. Angelis-Dimakis, A., Dimaki, K. (2016). Identifying Clusters of Regions in the European South, based on their Economic, Social and Environmental Characteristics. REGION, 3 (2), 71. doi: https://doi.org/10.18335/region.v3i2.81

19. Breznitz, D., Ornston, D. (2017). EU Financing and Innovation in Poland. SSRN Electronic Journal. doi: https://doi.org/10.2139/ ssrn.3119663

20. Pererva, P., Usov, M., Chernobrovkina, S., Larka, L., Rudyka, V. (2021). Methods for Assessing the Investment Attractiveness of Innovative Projects. Studies of Applied Economics, 39 (6). doi: https://doi.org/10.25115/eea.v39i6.5167

21. Domin, D. (2013). Artificial orthogonalization in searching of optimal control of technological processes under uncertainty conditions. Eastern-European Journal of Enterprise Technologies, 5 (9 (65)), 45-53. doi: https://doi.org/10.15587/ $1729-4061.2013 .18452$ 
22. Levchenko, I., Dmytriieva, O., Shevchenko, I., Britchenko, I., Kruhlov, V., Avanesova, N. et. al. (2021). Development of a method for selected financing of scientific and educational institutions through targeted capital investment in the development of innovative technologies. Eastern-European Journal of Enterprise Technologies, 3 (13 (111)), 55-62. doi: https://doi.org/10.15587/ 1729-4061.2021.235930

23. Vorkut, T., Volynets, L., Bilonog, O., Sopotsko, O., Levchenko, I. (2019). The model to optimize deliveries of perishable food products in supply chains. Eastern-European Journal of Enterprise Technologies, 5 (3 (101)), 43-50. doi: https://doi.org/10.15587/ 1729-4061.2019.177903

24. Orlowski, L. T. (2012). Financial crisis and extreme market risks: Evidence from Europe. Review of Financial Economics, 21 (3), 120-130. doi: https://doi.org/10.1016/j.rfe.2012.06.006

25. Novoe issledovanie Euler Hermes: vozdeystvie koronavirusa na global'nye otrasli. Available at: https://www.eulerhermes.com/ ru_RU/latest-news/ehru_2020_covid_uscherb_otraslyam.html

26. Impacts of the COVID-19 pandemic on EU industries. Available at: https://www.europarl.europa.eu/RegData/etudes/ STUD/2021/662903/IPOL_STU(2021)662903_EN.pdf

27. Pérez, S. T., Fana, M., González-Vázquez, I., Fernández-Macías, E. (2020). The asymmetric impact of COVID-19 confinement measures on EU labour markets. Available at: https://voxeu.org/article/covid-19-lockdown-and-eu-labour-markets

28. Baldwin, R., di Mauro, B W. (Eds.) (2020). Mitigating the COVID Economic Crisis: Act Fast and Do Whatever It Takes. CEPR Press.

29. Obsiah realizovanoi innovatsiynoi produktsiyi (tovariv, posluh) za vydamy ekonomichnoi diyalnosti. Derzhavna sluzhba statystyky. Statystychna informatsiya. Ekonomichna statystyka. Nauka, tekhnolohiyi ta innovatsiyi. Available at: http://www.ukrstat.gov.ua/ 